\title{
Characterization and hormonal modulation of immunoreactive thiamin carrier protein secreted by adult rat Leydig cells in vitro
}

\author{
S Subramanian and P R Adiga \\ Department of Molecular Reproduction, Development and Genetics, Indian Institute of Science, Bangalore 560 012, India \\ (Requests for offprints should be addressed to P R Adiga)
}

\begin{abstract}
Leydig cells isolated from adult rats and maintained under defined conditions in culture secrete a protein of molecular weight $\left(M_{\mathrm{r}}\right) 70000$ which is immunologically similar to chicken thiamin carrier protein (TCP). Synthesis of immunoreactive TCP by these cells is demonstrated by immunoprecipitation of $\left[{ }^{35} \mathrm{~S}\right]$ methionine incorporated, newly synthesized proteins with monoclonal and polyclonal antibodies to chicken TCP. The amount of immunoreactive TCP secreted into the culture supernatant is quantitated by using a specific radioimmunoassay. Under the influence of $\mathrm{LH}$, secretion of immunoreactive TCP is enhanced 3 -fold and can be inhibited by up to

$70 \%$ with aromatase inhibitor (1,4,6-androstatrien-3,17dione). Cyclic AMP acts as a second messenger in the sequence of events involved in LH-induced elevation of immunoreactive TCP in Leydig cells. The effects of exogenous estradiol-17 $\beta$ and diethylstilbestrol are comparable in terms of stimulation of secretion of immunoreactive TCP by these cells. Tamoxifen brought about a $70 \%$ decrease in the elevated levels of immunoreactive TCP. These results suggest that estrogen mediates immunoreactive TCP induction in hormonally stimulated adult rat Leydig cells.

Journal of Endocrinology (1999) 162, 49-56
\end{abstract}

\section{Introduction}

Thiamin carrier protein (TCP) from chicken egg yolk is a monomer of molecular weight $\left(M_{\mathrm{r}}\right) 70000$ which binds the free vitamin in preference to its phosphorylated analogs with an affinity constant of $0.3 \times 10^{9} \mathrm{M}^{-1}$. Chicken TCP is an estrogen-inducible, acidic, nonglycoprotein lacking in cysteine residues (Subramanian et al. 1996a). TCP is induced during the reproductive phase for deposition of adequate amounts of thiamin in the developing oocytes in oviparous species and to transport the vitamin across the placental barrier in mammals (Subramanian et al. 1996b). Recent findings from our laboratory reveal that the physiological functions of this protein are not confined to vitamin transport through the oocyte or placental barrier in the female but include other reproductive functions involving physiological barriers indicating additional biological roles such as in spermatogenesis. Supportive evidence for this premise stems from the experiments where immunoreactive TCP could be immunohistochemically localized, within the rat testis sections, to both the Leydig and Sertoli cells as well as to the developing germ cells (Subramanian \& Adiga 1999). Since Sertoli and Leydig cells are the major sites of synthesis for a wide variety of secretory proteins, hormonal modulation of immunoreactive TCP in these cell types in culture was investigated in detail. Recent investigations from this laboratory have demonstrated that immature rat
Sertoli cells in culture synthesize and secrete immunoreactive TCP which is modulated by in situ synthesized estradiol-17 $\beta$ under the influence of follicle-stimulating hormone (FSH) and testosterone or exogenously added steroid hormone (Subramanian \& Adiga 1999). In the present communication, investigations pertaining to identification of immunoreactive TCP in Leydig cells isolated from adult rats, its immunochemical characterization and hormonal modulation of secretion are described.

\section{Materials and Methods}

\section{Materials}

Dulbecco's Modified Eagle's Medium (DME)/F-12 powder, methionine-free DME medium, phenol red-free DME/F-12 medium, Percoll, estradiol-17 $\beta$, cholera toxin, 8-bromoadenosine $3^{\prime}: 5^{\prime}$ cyclic monophosphate, and diethylstilbestrol were purchased from Sigma Chemical Co. (St Louis, MO, USA). DEAE-Sephacel and S-Sepharose were procured from Pharmacia Fine Chemicals (Uppsala, Sweden). Tamoxifen was obtained from Spuart Pharmaceuticals (Wilmington, DE, USA). Purified ovine luteinizing hormone (LH) was a kind gift from Prof. N R Moudgal of this Institute. $\left[{ }^{35} \mathrm{~S}\right]$ Methionine, $\left[{ }^{3} \mathrm{H}\right]$ estradiol (specific activity $149 \mathrm{Ci} / \mathrm{mmol}$ ) and carrier-free $\mathrm{Na}^{125} \mathrm{I}$ were purchased from Amersham International plc. 
(Amersham, Bucks, UK). The specific antiserum raised in rabbits against estradiol-hemisuccinate was a kind gift from Prof. A J Rao of this Institute. The rest of the chemicals were of analytical grade and were obtained locally. Adult male rats (Wistar) used for isolation of Leydig cells were from the Institute's central animal facility.

\section{Isolation of Leydig cells}

From 60-day-old rats killed by cervical dislocation, testes were dissected and placed in DME/F-12 medium under sterile conditions. Interstitial tissue was obtained by collagenase dispersion of decapsulated testes (Dufau et al. 1974). Further, Leydig cells were fractionated by Percoll density centrifugation (Schumacher et al. 1978). To determine the proportion of Leydig cells in the cell preparation, histochemical staining for $\Delta^{5}-3 \beta$-hydroxysteroid dehydrogenase was performed by the method of Mendelson et al. (1975). The stained cells were evaluated by light microscopy for the presence of dark blue formazan deposits.

The highly purified Leydig cells were maintained in DME/F-12 medium with the addition of $20 \mathrm{mg} / 1$ gentamycin and at a density of $4 \times 10^{5}$ cells $/ \mathrm{cm}^{2}$ area at $32{ }^{\circ} \mathrm{C}$ in a humidified atmosphere of $5 \% \mathrm{CO}_{2}$. The spent media were collected and replenished with fresh media after every $24 \mathrm{~h}$.

\section{Purification of chicken TCP and production of antibodies}

TCP from chicken egg yolk was purified to homogeneity and polyclonal antibodies (pAbs) were raised against this protein in rabbits (Subramanian et al. 1996b). Various monoclonal antibodies (mAbs) to chicken TCP were raised and characterized earlier (Subramanian et al. 1996a). These were used as immunological probes for characterization of TCP in culture filtrates.

\section{Radioimmunoassay}

Chicken TCP was radioiodinated by the iodogen method (Fraker \& Speck 1978). A liquid phase radioimmunoassay (RIA) was developed using rabbit anti-chicken TCP antibodies and ${ }^{125}$ I-labeled chicken TCP as the tracer. The culture supernatants were 100-fold concentrated by ultrafiltration using YM-10 membranes (Amicon, Danvers, MA, USA). Varying amounts of concentrated culture supernatants were incubated with ${ }^{125}$ I-labeled chicken TCP (approx. $10^{5}$ c.p.m.) and its antiserum (1:40 000 dilution). Antibody-bound radioactivity was quantitated by double antibody-polyethylene glycol precipitation (Karande et al. 1991). The results were expressed in terms of chicken TCP as the standard.

\section{Immunoprecipitation}

To enrich the protein moiety, pooled Leydig cell culture supernatant was subjected to diethyl amino ethyl (DEAE)-
Sephacel column chromatography using $20 \mathrm{mM}$ phosphate buffer, $\mathrm{pH} 6 \cdot 0$. The bound proteins were eluted with $0.5 \mathrm{M} \mathrm{NaCl}$, dialyzed and passed through an S-Sepharose column pre-equilibrated with $20 \mathrm{mM}$ acetate buffer, $\mathrm{pH} 4 \cdot 8$. The bound proteins were eluted with $0.5 \mathrm{M} \mathrm{NaCl}$, dialyzed, concentrated and iodinated with $\mathrm{Na}^{125}$ I by the iodogen method (Fraker \& Speck 1978). The labeled proteins (approx. $10^{6}$ c.p.m.) were immunoprecipitated with either $\mathrm{pAb}$ or $\mathrm{mAb}$ to chicken TCP as described earlier (Subramanian \& Adiga 1996a).

\section{In vitro labeling and immunoprecipitation of Leydig cell secreted proteins}

Following preculture for $24 \mathrm{~h}$, the cells were incubated for $1 \mathrm{~h}$ in the methionine-free medium. Subsequently, the medium was supplemented with $10 \mu \mathrm{Ci} / \mathrm{ml}\left[{ }^{35} \mathrm{~S}\right]$ methionine (specific activity $500 \mathrm{Ci} / \mathrm{mmol}$ ) and the culture continued for another $10 \mathrm{~h}$. The supernatant was collected and the total $\left[{ }^{35} \mathrm{~S}\right]$ methionine incorporated into the secreted proteins was estimated following trichloroacetic acid $(10 \% \mathrm{w} / \mathrm{v})$ precipitation (Subramanian \& Adiga 1996b). The radiolabeled secreted proteins (approx. $3-4 \times 10^{6}$ cells) were precipitated with pAbs to chicken TCP and the immunoprecipitates resolved on SDS-PAGE were analyzed by fluorography as described earlier (Subramanian \& Adiga 1996b).

\section{Estimation of estradiol-17 $\beta$ by radioimmunoassay}

The spent medium was collected and concentrated 10-fold in a speedvac concentrator (Savant Instruments Inc., Farmingdale, NY, USA). The samples $(100 \mu \mathrm{l})$ were deproteinized with $20 \mu \mathrm{l}$ methanol and the steroids extracted with diethyl ether $(5 \mathrm{ml})$. The ether layers were evaporated to dryness and the samples were reconstituted in $100 \mu \mathrm{l} 0 \cdot 1 \%(\mathrm{w} / \mathrm{v})$ gelatin in PBS. The amount of estrogen present was determined by RIA (Haning et al. 1974).

\section{Statistical analysis}

The data obtained from each set of experiments which have been repeated at least four times were analyzed by Student's $t$-test. The interassay coefficient of variation for the RIA was found to be $<10 \%$.

\section{Results}

To obtain the Leydig cell enriched population, initially interstitial cells were subjected to Percoll density gradient centrifugation. With this technique, four bands of cells were visualized. Each band was individually collected and stained for 3 3 -hydroxysteroid dehydrogenase activity as the specific marker for Leydig cells. After staining, 


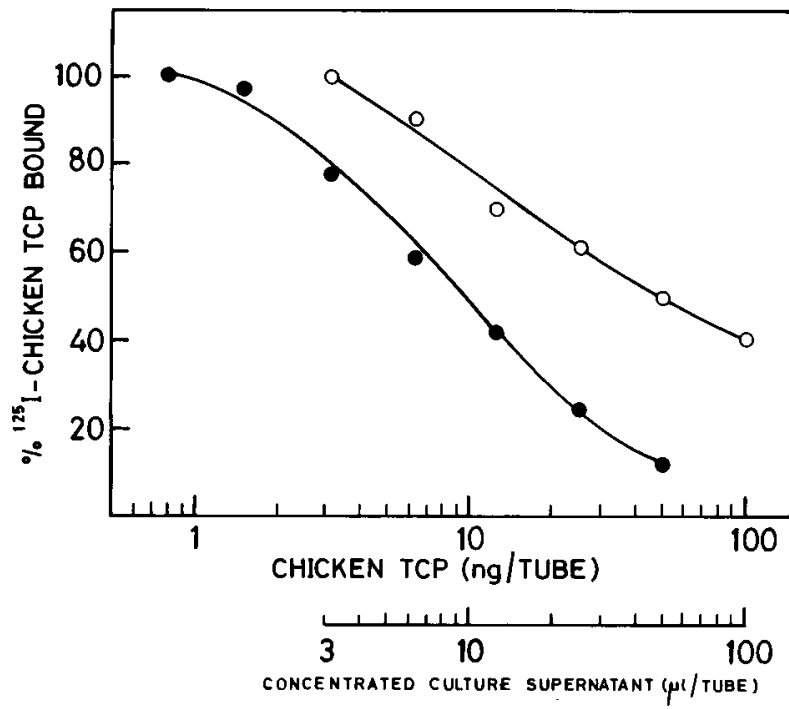

Figure 1 Inhibition of binding of ${ }^{125} \mathrm{I}$-labeled chicken TCP to its antiserum by unlabeled chicken TCP $(\mathbf{0})$ or concentrated Leydig cell culture supernatant $(\bigcirc)$. Data are expressed as the percentage of ${ }^{125}$ l-labeled chicken TCP bound in the presence of the unlabeled antigens.

microscopic examination of cells from individual bands revealed the presence of thick formazan deposits in $>85 \%$ of the cells (data not shown) derived from band 3 (from the top). Hence, for further studies, cells from band 3 were collected and maintained in serum-free DME/F-12 medium. In the present investigations, Leydig cells isolated from 60-day-old animals were chosen because in rats, these cells reach the maximum number i.e. $2.5 \times 10^{6}$ cells per testis by the end of puberty (day 56) (Saez 1994). Additionally, Leydig cells from adult rats are the major site of steroid aromatization which is stimulated by LH (Canick et al. 1979, Pomerantz 1979, Valladares \& Payne 1981, Tsai-Morris et al. 1985a).

\section{Immunochemical characterization of Leydig cell secreted immunoreactive thiamin carrier}

To identify the secreted vitamin carrier, the cells were maintained in serum-free DME/F-12 medium for $48 \mathrm{~h}$ to collect the spent medium which was then concentrated 100-fold, and liquid phase RIA was carried out to examine the ability of the protein fraction of the spent medium to inhibit the binding of ${ }^{125} \mathrm{I}$-labeled chicken TCP to the suitably diluted anti-chicken TCP serum. The dosedependent inhibition curve obtained (Fig. 1) shows that immunologically similar TCP is secreted by Leydig cells. Based on chicken protein standards, approx. $1.125 \mathrm{ng}$ immunoreactive $\mathrm{TCP} / 10^{6}$ cells $/ 48 \mathrm{~h}$ (equivalent to 16 fmoles) was encountered in the culture filtrate.

With a view to demonstrating the de novo synthesis of immunoreactive TCP, Leydig cells were incubated

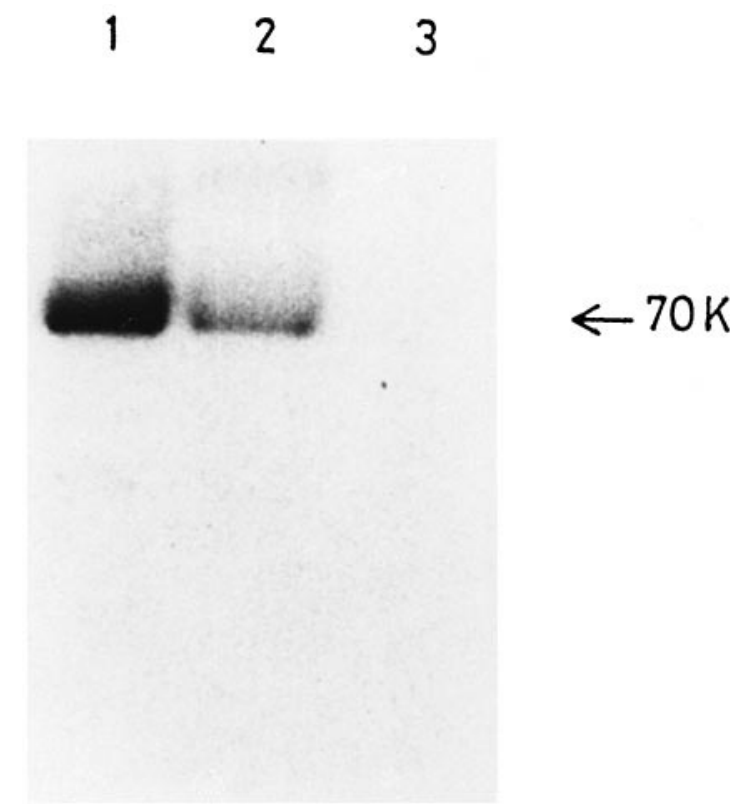

Figure 2 Fluorogram of ${ }^{35} \mathrm{~S}$-labeled Leydig cell proteins precipitated with polyclonal anti-chicken TCP antibodies. ${ }^{125}$ I-Labeled chicken TCP (lane 1, as a reference), and proteins precipitated with either chicken TCP antiserum (lane 2) or pre-immune rabbit serum (lane 3 ) are shown.

with $\left[{ }^{35} \mathrm{~S}\right]$ methionine and the culture fluid containing the newly synthesized/secreted proteins was immunoprecipitated with specific antibodies and analyzed by SDS-PAGE followed by fluorography. A radioactive band with a mobility comparable to that of avian TCP was clearly visible (Fig. 2) which conclusively shows the synthesis of immunoreactive TCP by Leydig cells in culture.

To characterize the immunospecificity of the Leydig cell TCP further, the secreted protein was enriched by sequential anion and cation exchange chromatography as described earlier. These partially purified proteins were radioiodinated and precipitated with five different $\mathrm{mAbs}$ specific to chicken TCP available in the laboratory (Subramanian et al. 1996a). The immune complexes were analyzed by SDS-PAGE and autoradiography. We have shown earlier that affinities $\left(K_{\mathrm{a}}\right)$ of these mAbs (A4C4, F3H6, H8H3, C8C1 and G7H10) to chicken TCP are of the order of $10^{9} \mathrm{M}^{-1}$. They all belong to the immunoglobulin G1 subclass with kappa type of light chains, and recognize non-overlapping epitopes as ascertained by chequer board analysis. Among these mAbs, passive immunization of pregnant rats with the mAb C8C1 only on three consecutive days of pregnancy (days 10, 11 and 12) resulted in embryonic resorption, thus indicating the bioneutralizing potential of this $\mathrm{mAb}$ to TCP during pregnancy in rats (Subramanian et al. 1996a). The results presented in Fig. 3 reveal that all the five mAbs to the 


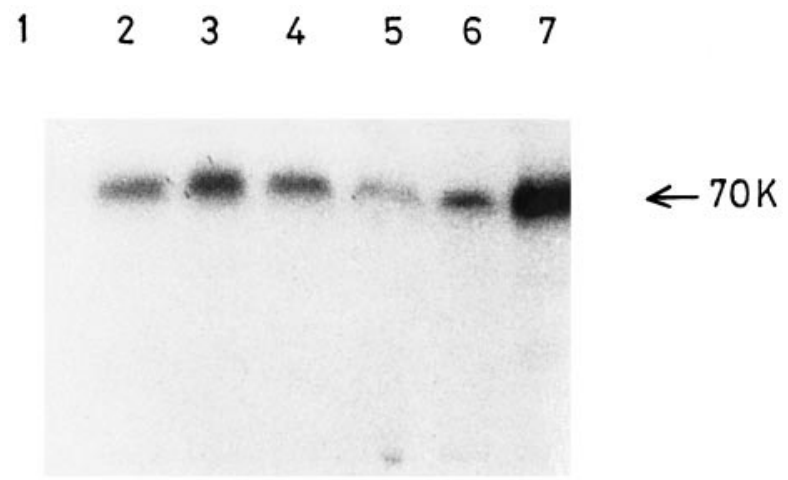

Figure 3 Autoradiogram of Leydig cell proteins immunoprecipitated with mAbs to chicken TCP. Immunoprecipitation with normal mouse serum (lane 1 , as a negative control), and with mAbs F3H6 (lane 2), A4C4 (lane 3), C8C1 (lane 4), H8H3 (lane 5) and G7H10 (lane 6) is shown. ${ }^{125}$ I-Labeled chicken TCP was loaded as a reference (lane 7).

avian TCP are capable of recognizing the Leydig cell secreted protein. These findings clearly show that the different epitopes recognized by all the monoclonal antibodies to the chicken TCP are conserved in the rodent testicular TCP-like protein.

Influence of various hormones on secretion of immunoreactive thiamin carrier by Leydig cells

Having established that Leydig cells in culture synthesize and secrete a specific protein with immunological homology with the chicken egg thiamin carrier, it was of interest to investigate the hormonal basis of its regulation. It is known from our earlier studies that the thiamin carrier is under the regulation of estradiol in chickens as well as in female rodents during reproduction (Sarada 1996). Hence, the possibility of the modulation of immunoreactive TCP in Leydig cells by the same steroid hormone was explored. Since estrogen production in the adult rat Leydig cell is influenced by LH (Tsai-Morris et al. 1985a,b), optimal concentrations of the gonadotropin required for maximal stimulation of secretion of immunoreactive TCP was determined (Table 1). The results show that $\mathrm{LH}$ stimulates the secretion of immunoreactive TCP in a dosedependent manner with maximal stimulation at a concentration of $100 \mathrm{ng} / \mathrm{ml}$ of the tropic hormone. Binding of this gonadotropin to its receptor on Leydig cells leads to initiation of a cascade of intracellular events among which is the stimulated aromatase activity leading to enhanced estradiol production (Tsai-Morris et al. 1985a,b). The results presented in Table 2 regarding the secretion of estradiol in the presence of $\mathrm{LH}$ are in agreement with these findings. At a concentration of $100 \mathrm{ng} / \mathrm{ml}$ of the gonadotropin, secreted estradiol levels increased approx. four times in comparison to the control values. Hence, it is conceivable that the 3 -fold stimulation of immunoreactive
Table 1 Effect of various concentrations of $\mathrm{LH}$ on immunoreactive TCP secretion by Leydig cells. Each value represents the mean \pm S.D.

\begin{tabular}{|c|c|c|}
\hline & $\begin{array}{l}\text { No. of } \\
\text { determinations }\end{array}$ & $\begin{array}{l}\text { ng TCP } / 10^{6} \\
\text { cells } / 48 \mathrm{~h}\end{array}$ \\
\hline \multicolumn{3}{|c|}{$\begin{array}{l}\text { Concentration of } \mathbf{L H} \\
(\mathrm{ng} / \mathrm{ml})\end{array}$} \\
\hline 0 & 12 & $1 \cdot 125 \pm 0 \cdot 21$ \\
\hline 1 & 4 & $1 \cdot 121 \pm 0 \cdot 14$ \\
\hline 10 & 4 & $1 \cdot 34 \pm 0 \cdot 11$ \\
\hline 25 & 4 & $1 \cdot 96 \pm 0 \cdot 20$ \\
\hline 50 & 4 & $2 \cdot 62 \pm 0 \cdot 22$ \\
\hline 100 & 12 & $3 \cdot 50 \pm 0 \cdot 31$ \\
\hline 200 & 4 & $3 \cdot 51 \pm 0 \cdot 35$ \\
\hline
\end{tabular}

Cells were maintained in DME/F-12 medium and protein levels from culture filtrates in $48 \mathrm{~h}$ were determined.

TCP secretion observed in the presence of LH is due to in situ synthesized estrogen under gonadotropin regulation. Confirmatory evidence for this hypothesis stems from experiments wherein cells maintained with aromatase inhibitor (1,4,6-androstatrien-3,17-dione) together with LH showed much reduced secretion of immunoreactive TCP (Fig. 4), accounting for $70 \%$ inhibition of the elevated levels due to stimulation by LH only, i.e. in the absence of the inhibitor. Thus, these results reveal that in Leydig cells, aromatase activity increases the synthesis of estrogen which, in turn, modulates the secretion of the vitamin carrier through autocrine/intracrine means.

Now the question arises whether this stimulation of immunoreactive TCP secretion by LH is mimicked by intracellular mediators of gonadotropin action viz. cyclic AMP. Our data seem to support this premise. Thus, cholera toxin $(1 \mu \mathrm{g} / \mathrm{ml})$, a direct and potent stimulator of adenylyl cyclase, and 8-bromo-cyclic AMP $(0.5 \mathrm{mM})$, a permeable analog of cyclic AMP could effectively mimic the action of LH (Fig. 5) in terms of secretion of the carrier protein. These findings are in line with the postulate that cyclic AMP acts as the second messenger in the sequence of events involved in LH-induced elevation of immunoreactive TCP in Leydig cells.

Table 2 Estradiol $\left(E_{2}\right)$ accumulation in the incubation medium by adult rat Leydig cells in the presence of various concentrations of $\mathrm{LH}$. Each value represents the mean \pm S.D.

\begin{tabular}{|c|c|c|}
\hline & $\begin{array}{l}\text { No. of } \\
\text { determinations }\end{array}$ & $\begin{array}{l}\text { pg } E_{2} / 10^{6} \\
\text { cells } / 24 h\end{array}$ \\
\hline \multicolumn{3}{|c|}{$\begin{array}{l}\text { Concentration of } \mathbf{L H} \\
(\mathrm{ng} / \mathrm{ml})\end{array}$} \\
\hline 0 & 6 & $2 \cdot 5 \pm 0 \cdot 3$ \\
\hline 1 & 4 & $2 \cdot 7 \pm 0 \cdot 24$ \\
\hline 10 & 4 & $3 \cdot 6 \pm 0 \cdot 31$ \\
\hline 50 & 4 & $5 \cdot 8 \pm 0 \cdot 42$ \\
\hline 100 & 4 & $9 \cdot 2 \pm 0 \cdot 74$ \\
\hline
\end{tabular}




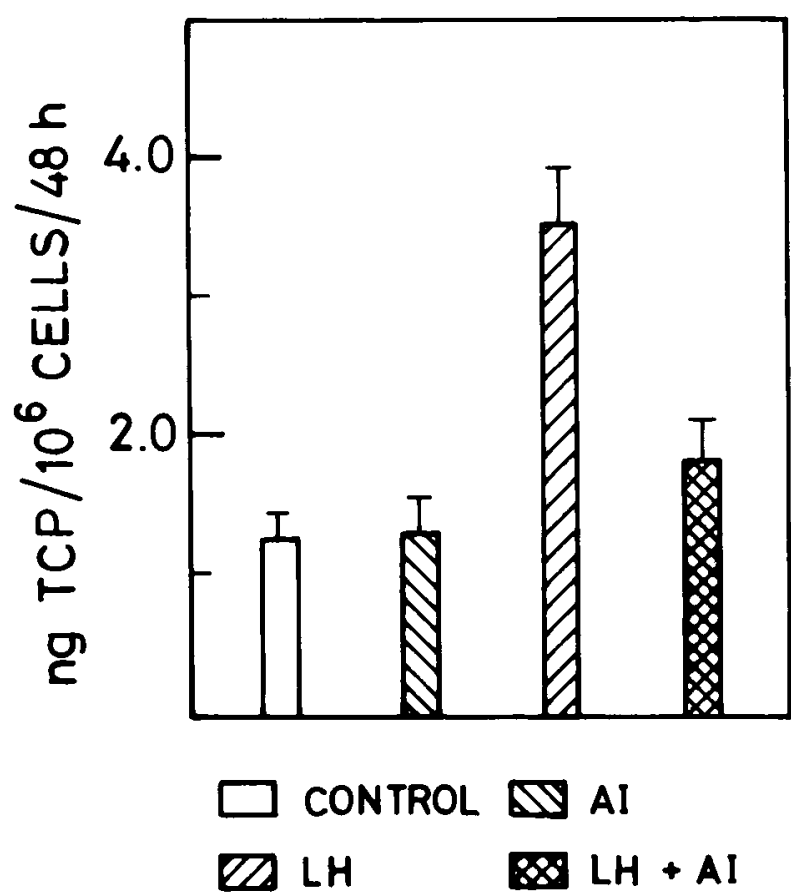

Figure 4 The effect of aromatase inhibitor (AI) on $\mathrm{LH}$-induced secretion of immunoreactive TCP by Leydig cells in culture. After $24 \mathrm{~h}$ in culture, $\mathrm{LH}(100 \mathrm{ng} / \mathrm{ml})$ and $\mathrm{Al}(100 \mu \mathrm{M})$ alone or in combination were added and the secreted TCP was measured by RIA. Values are the means \pm S.D. of duplicate cultures from four experiments.

Direct evidence for estrogen involvement in the stimulated secretion of immunoreactive TCP becomes evident when increasing concentrations of exogenous estradiol-17 $\beta$ were added to the Leydig cell cultures which results in an increase (up to 3-fold) in immunoreactive thiamin carrier secretion (Table 3 ). It was observed that at $1 \mu \mathrm{M}$ and above, exogenously added estradiol-17 $\beta$ brought about a 3-fold stimulation of secretion of immunoreactive TCP. In addition, synthetic estrogen diethylstilbestrol could also enhance the secreted protein levels albeit at relatively higher concentrations. This degree of stimulation is comparable in magnitude to that elicited by in situ synthesized estradiol-17 $\beta$. The specificity of estradiol induction is further substantiated by our finding that tamoxifen, an inhibitor of estrogen action could inhibit (70-80\%) enhanced secretion (Fig. 6) due to either $\mathrm{LH}$ or the exogenous steroid hormone.

\section{Discussion}

From the foregoing data it is clear that adult rat Leydig cells synthesize and secrete TCP-like protein in culture. The capacity of this protein to bind thiamin remains to be established at present since the ligand binding studies are

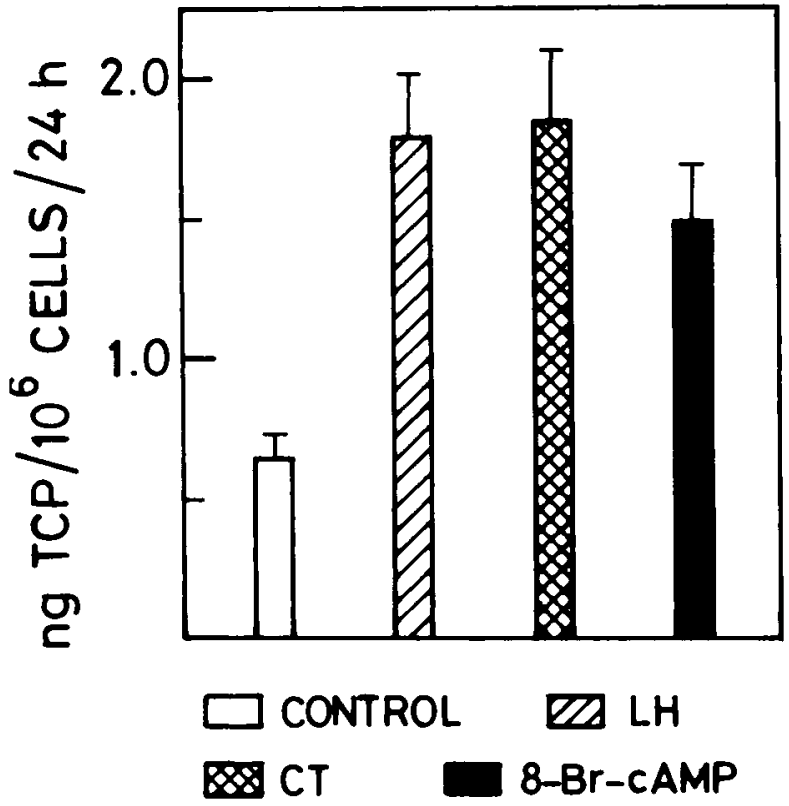

Figure 5 The influence of $\mathrm{LH}$, cholera toxin and 8-bromo-cyclic AMP (8-Br-cAMP) on the secretion of immunoreactive TCP by Leydig cells in vitro. The cells were maintained as described in the text. After $24 \mathrm{~h}, \mathrm{LH}(100 \mathrm{ng} / \mathrm{ml})$, cholera toxin $(\mathrm{CT} ; 1 \mu \mathrm{g} / \mathrm{ml})$ or 8-bromo-cyclic AMP $(0.5 \mathrm{mM})$ were added and the cells were cultured for another $24 \mathrm{~h}$. Values are the means \pm S.D. of duplicate cultures from four different experiments. Untreated cultures are designated as control.

handicapped owing to the availability of low amounts of the secreted protein ( 16 fmoles $/ 10^{6}$ cells $/ 48 \mathrm{~h}$ ), far below the affinity constant of its chicken counterpart towards the free vitamin $\left(0.3 \times 10^{9} \mathrm{M}^{-1}\right)$. However, detailed immunological characterization, including demonstration of cross-reactivity with five different mAbs against the chicken TCP favour the view that the Leydig cell protein

Table 3 Effect of various concentrations of estradiol and diethylstilbestrol on secretion of immunoreactive TCP by rat Leydig cells. Each value represents the mean \pm S.D.

\begin{tabular}{|c|c|c|}
\hline & $\begin{array}{l}\text { No. of } \\
\text { determinations }\end{array}$ & $\begin{array}{l}\text { ng TCP } / 10^{6} \\
\text { cells } / 48 \mathrm{~h}\end{array}$ \\
\hline \multicolumn{3}{|l|}{ Hormone } \\
\hline None & 6 & $1 \cdot 13 \pm 0 \cdot 17$ \\
\hline \multicolumn{3}{|l|}{ Estradiol } \\
\hline $0.01 \mu \mathrm{M}$ & 4 & $1 \cdot 1 \pm 0 \cdot 18$ \\
\hline $0 \cdot 1 \mu \mathrm{M}$ & 4 & $1 \cdot 6 \pm 0 \cdot 14$ \\
\hline $1 \cdot 0 \mu \mathrm{M}$ & 6 & $2 \cdot 8 \pm 0 \cdot 22$ \\
\hline $10 \cdot 0 \mu \mathrm{M}$ & 4 & $3 \cdot 0 \pm 0 \cdot 25$ \\
\hline \multicolumn{3}{|c|}{ Diethylstilbestrol } \\
\hline $1 \cdot 0 \mu \mathrm{M}$ & 4 & $1 \cdot 8 \pm 0 \cdot 19$ \\
\hline $10 \cdot 0 \mu \mathrm{M}$ & 4 & $2 \cdot 6 \pm 0 \cdot 24$ \\
\hline
\end{tabular}

Cells were maintained in DME/F-12 medium and protein levels from culture filtrates in $48 \mathrm{~h}$ were determined. 


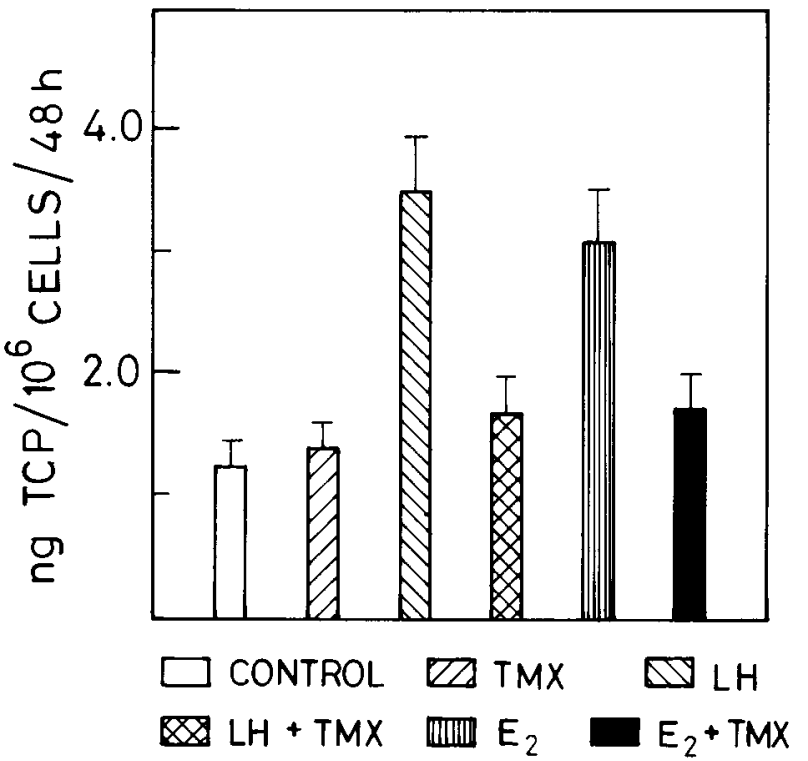

Figure 6 The effect of tamoxifen (TMX) on estradiol-induced immunoreactive TCP secretion by Leydig cells in culture. The cells were maintained in phenol red-free DME/F-12 medium for $24 \mathrm{~h}$ and then $\mathrm{LH}(100 \mathrm{ng} / \mathrm{ml})$, estradiol $(1 \mu \mathrm{M})$ and $\mathrm{TMX}(10 \mu \mathrm{M})$ were added alone or in the combinations shown and the secreted thiamin carrier levels were measured. Values are the means \pm S.D. of replicate cultures from four experiments.

shares with the avian vitamin carrier significant conformational characteristics dictated by constituent peptidyl sequences. As is evident from the data presented, the Leydig cell TCP-like protein appears to be primarily under the modulatory influence of estradiol produced in situ due to gonadotropin stimulation although it is not clear at present whether the steroid hormone functions through either autocrine or intracrine mode in this gonadal cell type. It has been well established that $\mathrm{LH}$ controls Leydig cell steroidogenesis by interaction with specific membrane receptors initiating membrane coupling events (Dufau et al. 1984). Among the processes initiated in the plasma membrane are the hormone-induced guanyl nucleotide binding, GTP-dependent membrane phosphorylation (Winters \& Dufau 1984), and adenylate cyclase activation leading to elevation of intracellular cyclic AMP (Dufau et al. 1980) which, in turn, activates the androgen biosynthetic pathway with increased testosterone production. Furthermore, early cyclic AMP activation of aromatase activity followed by enhanced substrate availability stimulates estradiol production (Tsai-Morris et al. 1985a,b). In fact, the data presented above favour the operation of the above sequence of events leading to enhanced immunoreactive TCP production since LH stimulation of immunoreactive TCP secretion is mimicked by agents stimulating intracellular cyclic AMP and is curtailed by the aromatase inhibitor. The above investigations also provide a biochemical probe with which to understand the functional significance of estradiol in male reproductive biology. Previous studies have shown that among the estrogen regulated proteins expressed in adult rat Leydig cells is a $28 \mathrm{kDa}$ gene product whose stimulation is curtailed by treatment with tamoxifen (Ciocca et al. 1986). This protein has been implicated in intracellular modulatory functions in the Leydig cell although its roles remain to be defined in molecular terms. Apart from the crucial role assigned to estrogen in regulating testicular steroidogenesis through influence on microsomal enzymes (17 $\alpha$-hydroxylase/ 17,20-desmolase) in the adult rat (Nozu et al. 1981, Aquilano \& Dufau 1983), other likely parameters modulated by this steroid in the Leydig cell functions remain to be explored. A recent report regarding LHregulated expression of estrogen sulfotransferase in adult rat Leydig cells (Song et al. 1997) provides indirect evidence for a need to fine-tune the regulatory role played by the locally synthesized estrogen in the testis of a sexually mature animal. This cytosolic enzyme catalyzes the specific sulfonation of estrogens which results in loss of binding to its receptor thus rendering the hormone inactive. The widespread expression of estrogen receptors in the testicular cells including Leydig cells (Fisher et al. 1997, Saunders et al. 1998) is consistent with the functional importance of estrogens in modulating spermatogenesis and hence fertility, in the male. Besides the immunoreactive TCP described in the present study, we have shown previously that immunoreactive riboflavin carrier protein (RCP) is synthesized and secreted by both Sertoli and Leydig cells under the influence of in situ synthesized estradiol (Subramanian \& Adiga 1996a,b). While the exact physiological relevance in molecular terms of these estrogen-regulated vitamin carriers has yet to be delineated, it is conceivable that they partake in the essential nutrient transport systems through the physiological barrier offered by Sertoli cell tight junctions to facilitate a directed mechanism to ensure uninterrupted supply of these water-soluble vitamins to rapidly proliferating and differentiating germ cells. In support of this premise is the recent observations in our laboratory that in the male rats actively immunized with the chicken RCP there occurs nearly $80 \%$ curtailment in fertility when they are mated with fertile non-immunized females (Adiga et al. 1997). This was predominantly attributable to fertilization failure and was unaccompanied by any changes in testosterone levels. Pending further elucidation of the molecular details involved therein, it is conceivable that in immature rats, the Sertoli cell vitamin carriers serve to sequester the respective ligands from the general circulation which are then transported to the germ cells. With the onset of puberty, the elaboration of the prime stimulator of vitamin carriers viz. estradiol decreases in Sertoli cells with a concomitant increase in the aromatase activity and production of estrogen in Leydig cells. In the rat, the capacity of the testis to synthesize estrogen depends mainly on the 
age of the animal. In immature rats, the main sites of aromatization are the Sertoli cells (Dorrington et al. 1978), and this activity is increased by FSH and all other factors able to increase intracellular cyclic AMP. In adult animals, however, Leydig cells are the major sites of aromatization, and this activity is stimulated by LH. At these later stages, under the influence of locally produced estradiol, Leydig cell carriers effectively sequester the vitamins from the circulation and deliver them in carrier-bound forms to the Sertoli cells presumably through a receptor-mediated mechanism, as in the case of serum transferrin (Morales et al. 1987). Once the vitamins gain entry, Sertoli cell synthesized carrier proteins under estrogenic influence from Leydig cells (Valladares \& Payne 1981) and/or germ cells (Nitta et al. 1993) capture the vitamins and ultimately transport them to the developing spermatogenic cells in the intratubular environment to subserve their uninterrupted proliferation and differentiation. In order to clarify these hypothetical sequences of events further elucidation of the underlying mechanisms require future investigation.

\section{Acknowledgements}

Financial assistance from the Department of Biotechnology, Government of India, New Delhi is acknowledged. P R A is supported by an Emeritus Scientist grant from the Council of Scientific and Industrial Research, New Delhi.

\section{References}

Adiga PR, Subramanian S, Rao J \& Kumar M 1997 Prospects of riboflavin carrier protein (RCP) as an antifertility vaccine in male and female mammals. Human Reproduction Update 3 325-334.

Aquiland DR \& Dufau ML 1983 Changes in ribonucleic acid polymerase activities in gonadotropin-treated Leydig cells: an estradiol-mediated process. Endocrinology 113 94-103.

Canick JA, Makris A, Gunsalus GL \& Ryan KJ 1979 Testicular aromatization in immature rats: localization and stimulation after gonadotropin stimulation in vivo. Endocrinology 104 285-288.

Ciocca DR, Winters CA \& Dufau ML 1986 Expression of an estrogen-regulated protein in rat testis Leydig cells. Journal of Steroid Biochemistry 24 219-229.

Dorrington JH, Fritz IB \& Armstrong DT 1978 Control of testicular estrogen synthesis. Biology of Reproduction 18 55-71.

Dufau ML, Mendelson S \& Catt KJ 1974 A highly sensitive in vitro bioassay for luteinizing hormone and chorionic gonadotropin: testosterone production by dispersed Leydig cells. Journal of Clinical Endocrinology and Metabolism 39 610-613.

Dufau ML, Baukal AJ \& Catt KJ 1980 Hormone induced guanyl nucleotide binding and activation of adenylate cyclase in the Leydig cell. Proceedings of the National Academy of Sciences of the USA $\mathbf{7 7}$ 5837-5841.

Dufau ML, Winters CA, Hattori M, Aquilano D, Baranao JLS, Nozu K, Baukal A \& Catt KJ 1984 Hormonal regulation of androgen production by the Leydig cell. Journal of Steroid Biochemistry 20 161-173.

Fisher JS, Millar MR, Majdic G, Saunders PT, Fraser HM \& Sharpe RM 1997 Immunolocalization of oestrogen receptor-alpha within the testis and excurrent ducts of the rat and marmoset monkey from perinatal life to adulthood. Journal of Endocrinology 153 485-495.
Fraker PJ \& Speck JC 1978 Protein and cell membrane iodinations with a sparingly soluble chloramide, 1,3,4,6-tetrachloro-3,6diphenyl glycouril. Biochemical and Biophysical Research Communications 80 849-857.

Haning R, Orczyk GP, Caldwell BV \& Behrman HR 1974 Plasma eatradiol, estrone, estriol, and urinary estriol glucuronide. In Methods of Hormone Radioimmunoassay, pp 675-700. Eds BM Jaffe \& HR Behrman. New York: Academic Press.

Karande AA, Velu NK \& Adiga PR 1991 A monoclonal antibody recognizing the $\mathrm{C}$-terminal region of chicken egg white riboflavin carrier protein terminates early pregnancy in mice. Molecular Immunology 28 471-478.

Mendelson C, Dufau M \& Catt KJ 1975 Gonadotropin binding and stimulation of cyclic adenosine $3^{\prime}: 5^{\prime}$-monophosphate and testosterone production in isolated Leydig cells. Journal of Biological Chemistry 250 8818-8823.

Morales C, Sylvester SR \& Griswold MD 1987 Transport of iron and transferrin synthesis by the seminiferous epithelium in vivo. Biology of Reproduction 37 995-1005.

Nitta H, Bunick D, Hess RA, Janulis L, Newton SC, Millette CF, Osawa Y, Shizuta Y, Toda K \& Bahr JM 1993 Germ cells of the mouse testis express P450 aromatase. Endocrinology 132 1396-1401.

Nozu K, Dehejia A, Zawistowich L, Catt KJ \& Dufau ML 1981 Gonadotropin-induced receptor regulation and steroidogenic lesions in cultured Leydig cells: induction of specific protein synthesis by chorionic gonadotropin and estradiol. Journal of Biological Chemistry $25612875-12882$.

Pomerantz DK 1979 Effects of in vivo gonadotropin treatment on estrogen levels in the testis of the immature rats. Biology of Reproduction 21 1247-1255.

Saez JM 1994 Leydig cells: endocrine, paracrine and autocrine regulation. Endocrine Reviews 15 574-626.

Sarada B 1996 Studies on vitamin carrier proteins: role of thiamin carrier protein in female reproduction and hormonal modulation of secretion of vitamin carrier proteins by rat testicular cells in culture. $P h D$ Thesis, Indian Institute of Science, Bangalore, India.

Saunders PT, Fisher JS, Sharpe RM \& Millar MR 1998 Expression of oestrogen receptor beta (ER beta) occurs in multiple cell types, including some germ cells, in the rat testis. Journal of Endocrinology 156 R13-R17.

Schumacher M, Schaffer G, Holstein AF \& Hiltz H 1978 Rapid isolation of mouse Leydig cells by centrifugation in Percoll gradient with complete retention of morphological and biochemical integrity. FEBS Letters 91 333-338.

Song WC, Qian Y, Sun X \& Negishi M 1997 Cellular localization and regulation of expression of testicular estrogen sulfotransferase. Endocrinology 138 5006-5012.

Subramanian S \& Adiga PR 1996a Hormonal modulation of riboflavin carrier protein secretion by immature rat Sertoli cells in culture. Molecular and Cellular Endocrinology 120 41-50.

Subramanian S \& Adiga PR 1996b Hormonal modulation of secretion of immunoreactive riboflavin carrier protein by adult rat Leydig cell in vitro. Indian Journal of Biochemistry and Biophysics $\mathbf{3 3}$ 274-280.

Subramanian S \& Adiga PR 1999 Characterization and hormonal modulation of immunoreactive thiamin carrier protein in immature rat Sertoli cells in culture. Journal of Steroid Biochemistry and Molecular Biology 68 23-30.

Subramanian S, Karande AA \& Adiga PR 1996a Establishment of the functional importance of thiamin carrier protein in pregnant rats by using monoclonal antibodies. Indian Journal of Biochemistry and Biophysics 33 111-115.

Subramanian S, Rao J \& Adiga PR 1996 b Active immunization of rats with chicken egg thiamin carrier protein results in early embryonic loss at peri-implantation stages. Indian Journal of Experimental Biology 34 302-306. 
Tsai-Morris C-H, Aquilano DR \& Dufau ML 1985a Cellular localization of rat testicular aromatase activity during development. Endocrinology 116 38-46.

Tsai-Morris C-H, Aquilano DR \& Dufau ML 1985 b Gonadotropic regulation of aromatase activity in the adult rat testis. Endocrinology 116 31-37.

Valladares LE \& Payne AH 1981 Effects of human chorionic gonadotropin and cyclic AMP on aromatization in purified Leydig cells of immature and mature rats. Biology of Reproduction 25 752-758.
Winters CA \& Dufau ML 1984 Characterization of Leydig cell membrane phosphorylation. International Congress of Endocrinology Abstract no. 2572.

Received 23 June 1998

Revised manuscript received 23 November 1998 Accepted 22 February 1999 